\title{
Evidence of osteomyelitis in Cuban aborigines
}

\author{
Sergio Morales Piñeiro ${ }^{1}$, Raúl Villavicencio Finalet ${ }^{2}$, Lourdes Morera Estévez ${ }^{3}$, Olivia Clavero Machado ${ }^{4}$, Claribel Plain Pazos ${ }^{5 *}$ Leonardo $^{*}$ \\ Domínguez Plain ${ }^{6}$ \\ ${ }^{1}$ II Degree Specialist in Orthopedics and Traumatology, Assistant Professor. Added Investigator. Provincial General University Hospital "Mártires \\ del 9 de Abril" Sagua la Grande. Villa Clara. Cuba. \\ ${ }^{2}$ Associate Professor of the Central University "Marta Abreu" of Las Villas. CITMA Associate Researcher. Villa Clara. Cuba. \\ ${ }^{3} \mathrm{MCs}$ in Higher Education. Assistant Professor of the Central University "Marta Abreu" of Las Villas. Villa Clara. Cuba. \\ ${ }^{4}$ Assistant Professor of the Central University "Marta Abreu" of Las Villas. Villa Clara. Cuba. \\ ${ }^{5}$ II Degree Specialist in Comprehensive General Medicine. Assistant Professor. Faculty of Medical Sciences of Sagua la Grande. Villa Clara. \\ ${ }^{6}$ Resident of 3rd year of Orthopedics and Traumatology. Provincial General University Hospital "Mártires del 9 de Abril" Sagua la Grande. Villa \\ Clara. Cuba.
}

*Corresponding author: Claribel Plain Pazos, Faculty of Medical Sciences of Sagua la Grande, Villa Clara, Cuba.

Received date: January 27, 2021; Accepted date: March 08, 2021; Published date: March 13,2021

Citation: Sergio M Piñeiro, Raúl V Finalet, Lourdes M Estévez, Olivia C Machado, Claribel P Pazos et al. (2021) Evidence of osteomyelitis in Cuban aborigines. Biomedical Research and Clinical Reviews. 3(4); DOI: 10.31579/2692-9406/046

Copyright: (C) 2021 Claribel Plain Pazos, This is an open-access article distributed under the terms of the Creative Commons Attribution License, which permits unrestricted use, distribution, and reproduction in any medium, provided the original author and source are credited.

\begin{abstract}
:
Paleopathology is the branch of science that is responsible for the study of diseases suffered by our ancestors, in Cuba some studies have been carried out on pathologies suffered by the aborigines. The objective is to present a specimen of human diaphyseal bone found in the funerary site of the "Cueva de los Chivos" in the Sumidero de Jibacoa Valley, Guamuhaya mountain massif, municipality of Manicaragua, Villa Clara province, Cuba in excavations carried out between the years 2000 and 2002 by the archeology group of the Center for Environmental Studies and Services of CITMA in Villa Clara.

Presentation: It is a tibia fragment due to its thickness and triangular shape with periosteal thickening, cortical irregularity and a large number of crypts, whose radiography shows the presence of bone sequestration with the corresponding involvement and signs of periostitis. The skeletal remains found show evidence of having suffered from chronic osteomyelitis. Based on the archaeological materials found at the funerary site, it was determined that these belonged to pre-agricultural pottery groups that populated the island between 2000 and 6000 years ago.

Conclusions: The Cuban aboriginal groups had elementary knowledge of orthopedic conditions such as bone infections and their treatment in all probability, evidenced by the chronicity of osteomyelitis presented in this specimen which survived for a period of time.
\end{abstract}

Key Words: aboriginal history; paleontology; paleopathology; orthopedic procedures; osteomyelitis

Paleopathology in the branch of science that is responsible for the study of conditions suffered by ancestors. The first studies carried out in Cuba were carried out in the 19th century by Poeyen 1865 and by Montané in the years 1874, 1877, 1885 and 1887 respectively [1]. Further into the 20th century by Rivero de la Calle in 1987 [2], Guarch Delmonte in 1996 [3] and Vento Canosa in 1999 [4]. In the XXI century, specifically in 2016, an article was published by the Feijó publishing house of the Central University "Marta Abreu" of Las Villas on the evidence of the treatment of fractures in Cuban aborigines [5] in which the first three authors of the present are participants. job. But as there was more evidence of bone pathologies among the samples collected, the objective of the article is to show a specimen of human diaphyseal bone (tibia) found in the funerary site of the "Cueva de los Chivos" in the Sumidero de Jibacoa Valley, a mountainous massif of Guamuhaya, municipality of
Manicaragua in the province of Villa Clara, in excavations carried out between 2000 and 2002 by the archeology group of the Center for Environmental Studies and Services of CITMA of Villa Clara, led by Raúl Villavicencio Finalet, and whose samples are found deposited in the property of the Municipal Museum of the city of Sagua la Grande, with the hypothesis that these natives had knowledge about different bone pathologies such as osteomyelitis and that they even treated them.

\section{Presentation of the specimen:}

It is a bony piece measuring $8 \mathrm{~cm}$ in length $\mathrm{X} 3 \mathrm{~cm}$ in width in a triangular shape, with all certainty a tibia with periosteal thickening, cortical irregularity and a large number of crypts. (Figure 1). An X-ray of the sample shows a central bone sequestration with involvement and peripheral periosteal reaction as well as cortical irregularity. (Figure 2) 


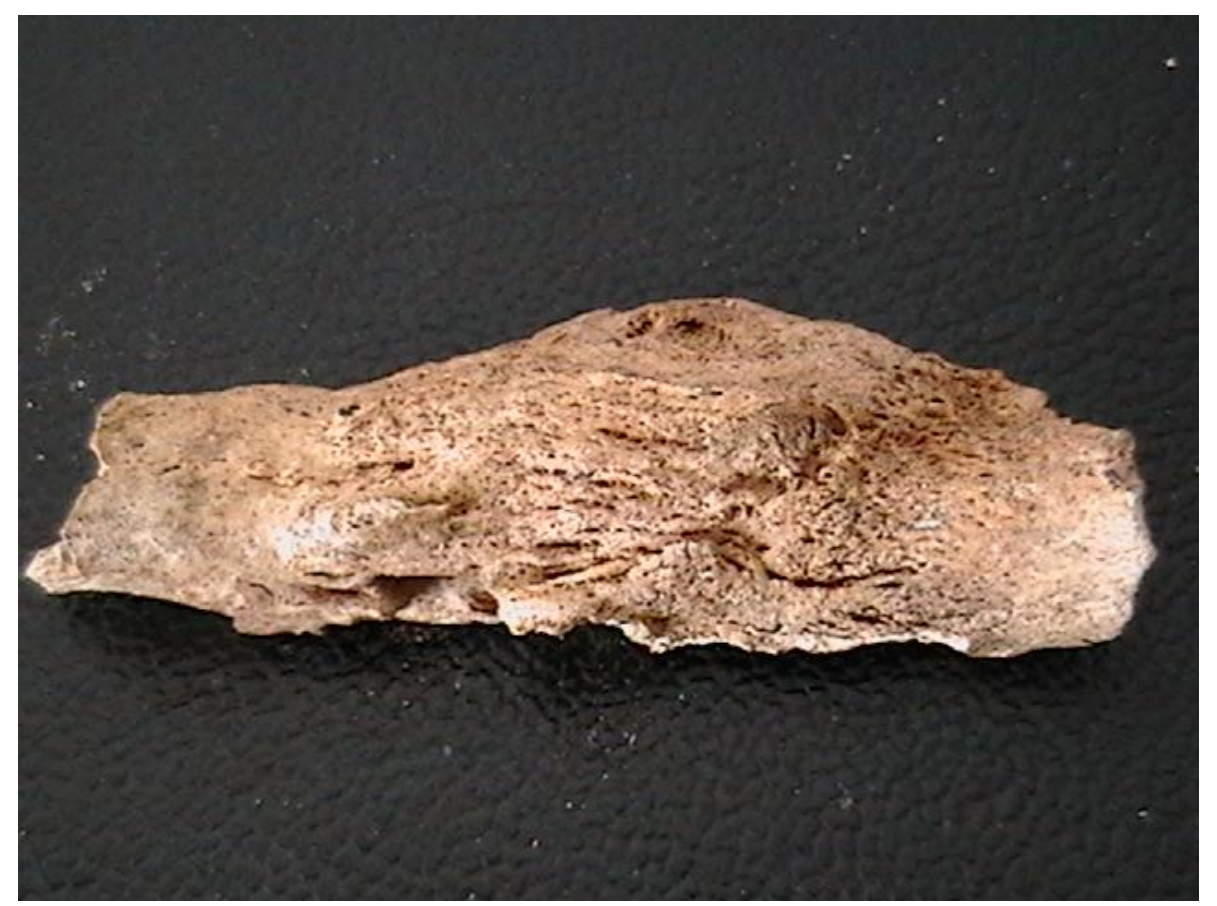

Figure 1: Tibia specimen measuring $8 \mathrm{~cm} \mathrm{X} 3 \mathrm{~cm}$ showing periosteal thickening, cortical irregularity and a large number of crypts.

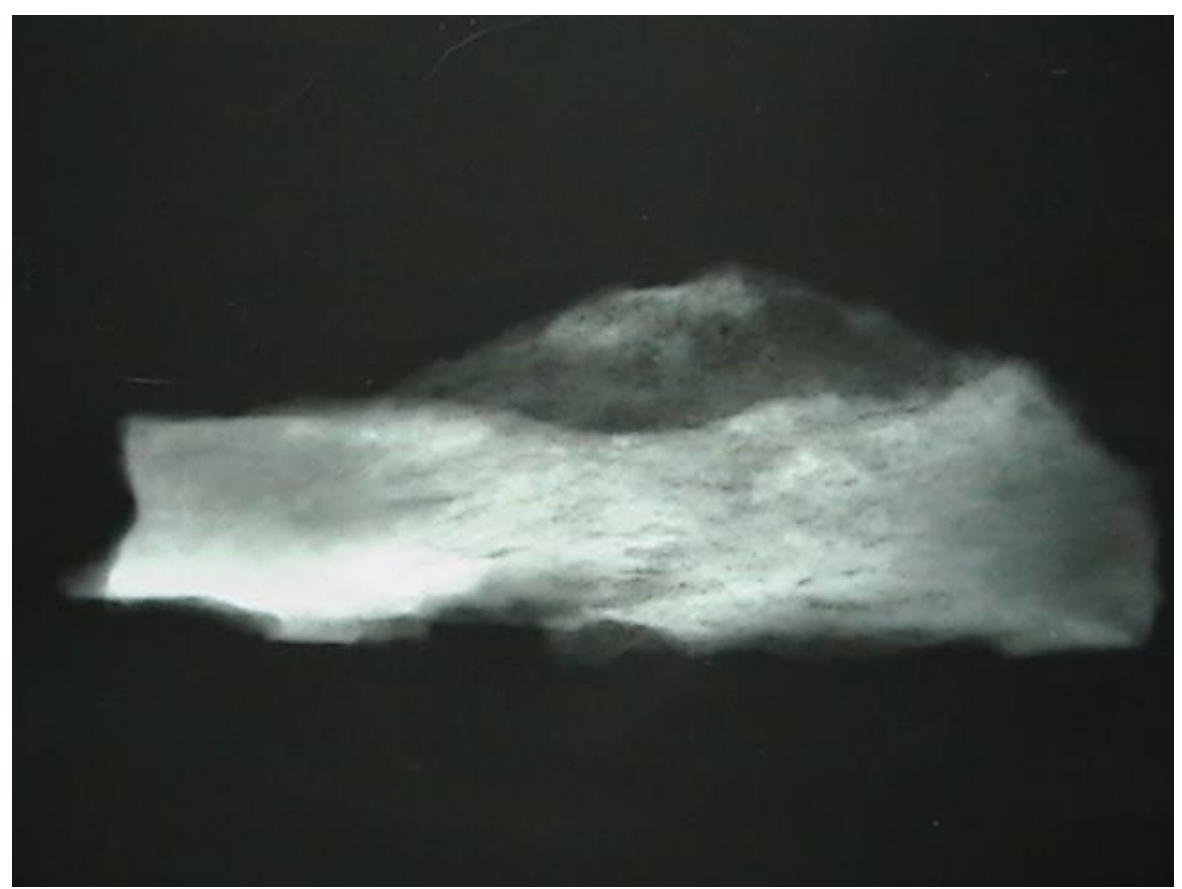

Figure 2: X-ray of the specimen showing a central bone sequestration with involvement and an important peripheral periosteal reaction.

\section{Discussion:}

The presented specimen belongs to the collection found in the "Cueva de los Chivos" in the Sumidero de Jibacoa Valley, Guamuhaya mountain massif, Manicaragua municipality in the Villa Clara province, Cuba; Primary funerary site with great archaeological wealth where 15 skeletons of children were also found in an astonishing state of preservation and other bone samples with a certain state of deterioration, such as those presented, as well as a funerary trousseau made up of numerous pieces of flint such as scrapers, burins, hammer, shells and others, synonymous with a carved stone industry in addition to the absence of elaborate ceramics, this made us think that these remains are between 2000 and 6000 years old and that they belonged to pre-agricultural pottery groups that populated Cuba at that time. [5,6] The ideal would be to date them with collagen or Carbon 14 tests to obtain the most exact dating possible but the well-known economic reasons of our times have prevented this, so we must support the method of the correlation that is not exact but allows us to mark these remains at certain stages.

Many could doubt the claim that the fragment found is a tibia, for that reason the authors were based on classifying the thickest tubular bones of 
the human body [humerus, femur and tibia] and of these the only one that has a triangular shape is the tibia, another possible factor of confusion would be to think that the fragment could belong to an animal, this is ruled out since the site is strictly human funerary and there are no remains of animals synonymous with the consumption of their meat, on the other hand this site is very well preserved with anthropic activity related to the archaeologists who explored it.

Osteomyelitis is found with relative frequency in excavations carried out in Latin America, in the archaeological site of "Chorro de Maita" in the province of Holguín in Cuba. The findings consisted of: non-specific inflammations or infections, degenerative joint disease, congenital conditions and neoplasms [6,7]. Very distant in South America samples were found that suggested bone tuberculosis. [8-10]

Most diseases do not leave their mark on the skeleton, and those that do can leave similar injuries to each other. However, based on the morphology and distribution of the lesions observed in the bones, we can sometimes establish paleodiagnostics. The paleopathological analysis of this piece in the case of the "Cueva de los Chivos" site made it possible to diagnose that the pathology suffered by the individual corresponded to osteomyelitis, defined as an inflammation of the bone tissue, produced mainly by the action of infectious agents, which affected the cortex, medulla and periosteum of the compromised bone.

\section{Conclusions:}

The Cuban aboriginal groups had elementary knowledge of orthopedic conditions such as bone infections and their treatment in all probability, evidenced by the chronicity of osteomyelitis presented in this specimen which survived for a period of time.

\section{References:}

1. Crespo-Torres E. (2019) The History of Paleopathologyin the Caribbean Archipelago. En: H. Ubelaker DH, Colantonio SE.
Biological Anthropology of Latin America: Historical Development and Recent Advances. Washington DC: Smithsonian Scholarly Press. 173-187.

2. Rivero de la Calle, M. (1987) Paleopatología de los aborígenes de Cuba. En Estudios de Antropología Biológica. Sáenz M. E,Lizarraga C. X. Mexico City. Mexico: UNAM. p475-498.

3. GuarchDelmonte, J. M. (1996) La muerte en las Antillas: Cuba. El Caribe Arqueológico. 1:12-25.

4. Vento, C. E.,Gonzalez R D. (1999) Paleopatología aborigen en Cuba. El Caribe Arqueológico. 1:31-38.

5. Morales Piñeiro S V, Villavicencio Finalet R, Morera Estévez L. (2016) Evidencias del tratamiento de fracturas en aborígenes cubanos. Memorias del VII Taller Universidad, Sociedad y Desarrollo sostenible en el siglo XXI..[CD ROM] Editorial Feijó.

6. Chinique de Armas Y, Roksandic M. Assessing the Biological and Cultural Diversity of Archaic Age Populations from Western Cuba. En:Ubelaker DH,.Colantonio SE. Biological Anthropology of Latin America: Historical Development and Recent Advances. Washington DC: SmithsonianScholarlyPress; 2019. p 161-171.

7. Weston, D. A., Varcarcel-Rojas R. (2016) Communities in contact. Health and paleodemography at el Chorro de Maita, Cuba. In Cuba Archaeology in the Caribbean, Gainesville: University Press of Florida. ed. I. Roksandic. p. 83-105.

8. Bos KI, Harkins KM, Herbig A, Coscolla M, Weber N, Comas I et al. (2014) Pre-Columbian mycobacterial genomes reveal seals as a source of New World human tuberculosis. Nature. 514:494-497.

9. Buzic I,V. Giuffra V. (2020) The paleopathological evidence on the origins of human tuberculosis: a review. J PrevMedHyg. Mar; 61[1 Suppl 1]: 3-8.

10. Jurado LF, Murcia MI, Arias J, Sánchez L. (2015) Mal de Pott en un indígena colombiano. Biomédica. 35[4]: 454-461.

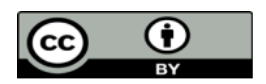

This work is licensed under Creative Commons Attribution 4.0 License

To Submit Your Article Click Here: Submit Manuscript

DOI: $10.31579 / 2692-9406 / 046$
Ready to submit your research? Choose Auctores and benefit from:

* fast, convenient online submission

* rigorous peer review by experienced research in your field

* rapid publication on acceptance

* authors retain copyrights

* unique DOI for all articles

* immediate, unrestricted online access

At Auctores, research is always in progress.

Learn more www.auctoresonline.org/journals/international-journal-ofclinical-case-reports-and-reviews 